日本臨床麻酔学会第 29 回大会シンポジウム 日臨麻会誌 Vol.31 No.1, $50 \sim 56,2011$

将来の病院経営戦略一そのとき麻酔科はどう動くか?

\title{
病院経営戦略を考えるうえでのDPC 分析の有用性とその限界
}

小林利彦*

[要旨] 急性期病院において経営戦略を立てるうえで，DPCに関する知識は必須と考えられ，それ は手術, 麻酔部門の職員でも同様と思われる. DPC 制度下で利益を増大させるために, ジェネリ ック薬の採用や画像検査等の外来移行が強調されるが, DPC 制度の根幹ともいえる適正コーディ ングによって収益増は期待できる. しかしながら，DPC 対象病院が出来高制度から移行したこと で得た利益は, 院内の病院情報システムの整備に投資すべきであり, 臨床指標等を積極的に公開し ていく姿勢が望まれる. 特に, 現在, 厚労省に提出しているDPCデータだけでなく, 院内には貴 重な生データがあることを再認識し, それらの有効活用を検討することも期待される.

キーワード : 診断群分類, 病院経営, 医療の質, 臨床指標, 診療報酬請求

\section{はじめに}

病院を評価するうえでの3要素としてHospitality, Quality, Sustainabilityがある. Hospitalityは Amenity とも関係するが，一般に数值化しにくく 可視化も困難である。一方, QualityはDonabedian AによるとStructure(構造), Process(経過), Outcome(結果)に分けられるが, これらは数值化・可 視化しやすく比較的評価も容易である。しかし，そ れらの根底にあるべきものとして Sustainabilityが 重要であり, それは病院経営における「継続性」, または人的確保面での「持続性」と表現(翻訳)でき る(図1).

本稿では, 病院経営面でのSustainability を確保 するうえで注目すべきシステムとして, 急性期病院 の過半数病床ですでに採用されているDPC(Diag- nosis Procedure Combination) 制度 ${ }^{1) \sim 4)}$ の概要を解 説し，同システムと手術室，麻酔科(医)とのかかわ りについて述べるとともに，いわゆる Clinical Indicator (臨床指標)の発信に向けて現状の DPC 制度で 可能なことと不可能なことに言及したい.

\section{DPC 関連病院の現況 ${ }^{4)}$}

2003 年に特定機能病院等 (82 施設) が DPC 制度を 採用してからすでに 7 年が経過した。 2009 年現在, DPC 制度に従い診療報酬請求をしている「DPC対 象病院」が1,283施設, DPC 関連情報を提供のみし ている「DPC準備病院」が 274 施設ある。両者を合 わせた DPC関連病院は 1,557 施設となるが，これは 2007 年の全国病院数 $(8,662$ 施設) の $18 \%$ に相当する (図2)。なお，ベッド数でみると，2007年の全国病 床数 (913,234 床) のうち DPC 関連病床は480,051床
著者連絡先 小林利彦

干 431-3192 静岡県浜松市東区半田山 1-20-1 浜松医科大学医学部附属病院 


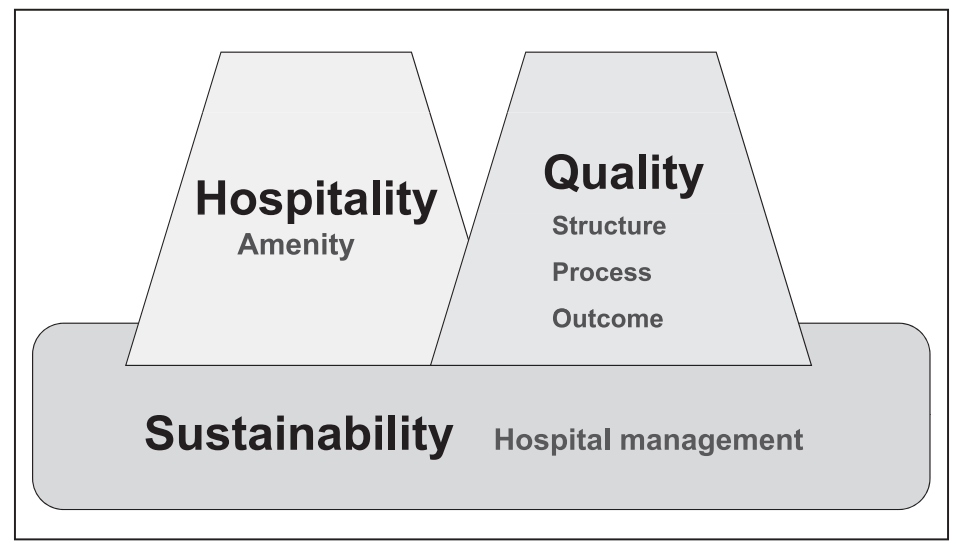

図1 病院を評価するうえでの3要素

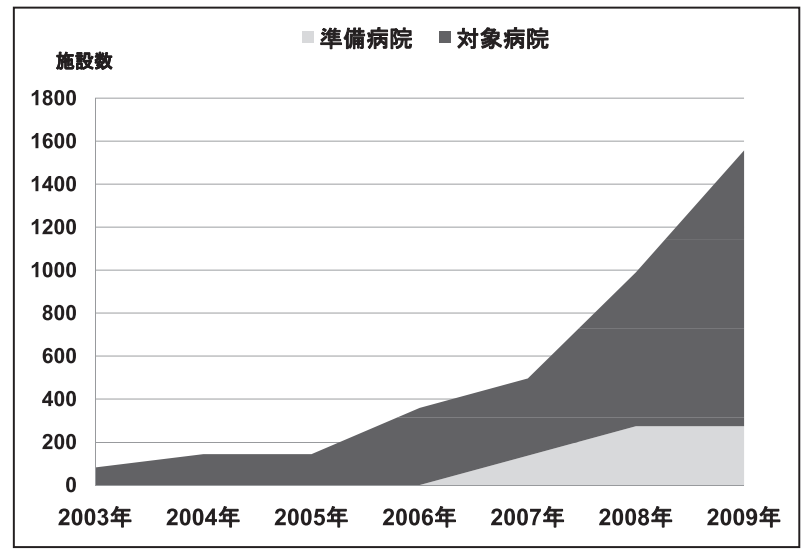

図2 DPC関連病院数の推移

(52.6\%) とすでに過半数を超えている.

また，ここ $1 〜 2$ 年の傾向として，200床未満の 病院またはケアミックス型病院の参入が目立ってお り，従来の大規模急性期病院と同一尺度で評価する ことが妥当か否かの議論もある。

\section{DPCの本質 ${ }^{2)}$}

$\mathrm{DPC}$ 対象病院にしてみると「DPC =レセプトツ ール」としてとらえられやすいが, DPCの本質は Casemix というカテゴリーツールにあり，それを用 いて診療内容の透明性を高めるとともに，その説明 責任を果たすことが望まれている。具体的にいうと， 診断(Diagnosis) には国際疾病分類 : ICD-10 (International Classification of Diseases and Related
Health Problems, 10th ed.)の病名を使用し, 手術・ 処置(Procedure)として各固有コードから選択した ものをCombinationすることで，14桁よりなる診 断群分類 (2008 年 4 月時点で 2,451 種類) が決定され る。その結果，同一の診断群分類における施設間比 較が可能となるわけだが，「医療資源を最も投入し た病名」を「主病名」として採用することから，そ のコーデイングの適否が診療報酬に大きく影響する ことになる.

\section{DPC 制度における診療報酬の収益構造 ${ }^{1) ~ 3) ~}$}

前述した 2,451 種類の診断群分類の中で， 1,572 分 類がいわゆる包括請求となる診断群である。その際 の診療報酬請求からみた収益構造を図3に示すが, 手術, 麻酔, 放射線治療など従来の出来高算定をす る区分と, 入院基本料, 投薬- 注射, 検査, 画像, 処置など包括算定する区分とに分けられる。なお， DPCで包括される総算定額は, 診断群分類と入院 期間，そして医療機関別係数によって計算される. 病院にとっては，包括算定額と出来高算定額の差 (図3で示す $\triangle \mathrm{DPC}$ ) が出来高制度から DPC 制度に 移行した際の利益となる。別の見方をすると，この $\triangle \mathrm{DPC}$ がマイナスであれば，DPC 対象病院になる 経営的メリットはないとも考えられる。ただし，こ の $\triangle \mathrm{DPC} に は ，$ 本制度採用に伴う現場職員の汗(労 


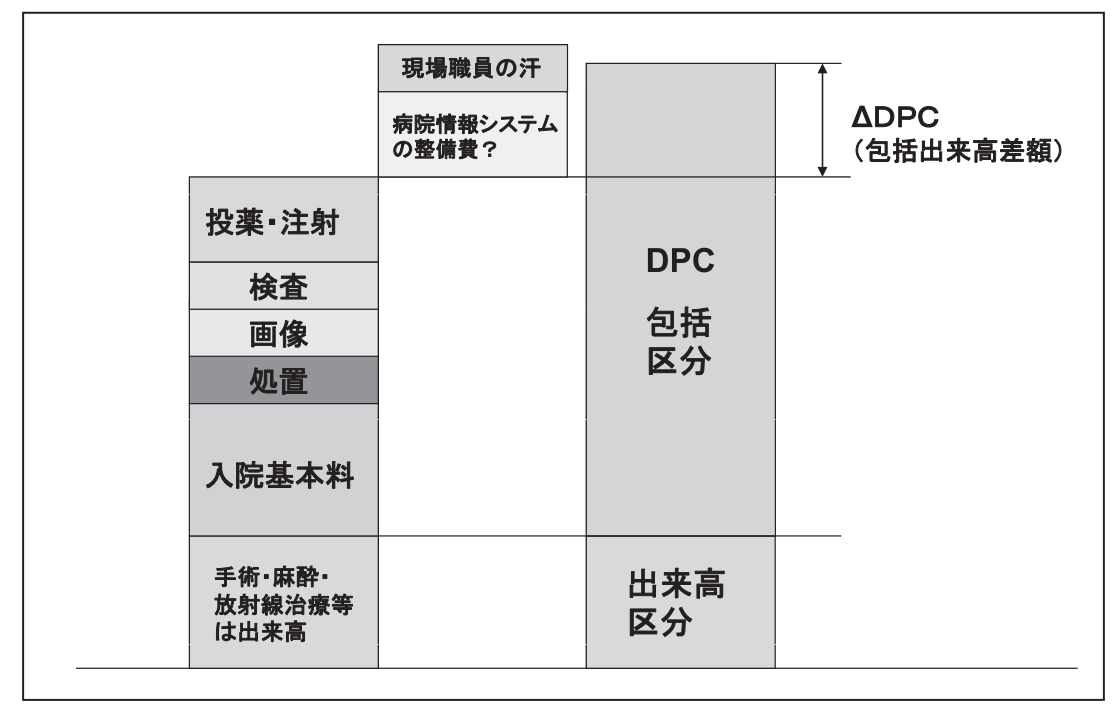

図3ＤPC制度における診療報酬の収益構造

働時間，手間など)や，病院情報システム整備への 対価が含まれることを忘れてはいけない.

手術室で勤務する麻酔科医や外科系医師にしてみ ると, 麻酔料や手術料が出来高算定であることから, 概してDPC制度に無頓着となりやすい。しかし， 本制度を俯瞰的にとらえれば明らかとなるが, 麻酔・ 手術時間が長いことで有利に衝くことは少なく，手 術室に勤務する職員にも本制度を意識したマネジメ ントが期待される。

\section{IVＤPC制度下で利益を上げるには？}

DPC 制度採用の有無に限らず，利益を上げるに は収益を上げるか，費用を下げるかしかない(図4). 収益増には出来高部分の増収と包括部分の増収が考 えられるが，前者には手術件数ならびに指導・管理 料等の増加が有効であり，後者にはいわゆる「アッ プコーディング」ではない「診断群分類の適正コー ディング」が重要となる。一方, 費用減では包括部 分の費用削減が有用であり, 代表的なところではジ エネリック薬の採用, 医療材料の変更, CT・MRI など画像検査の外来移行が考えられる。しかし, 診 療内容のスリム化が粗診粗療を招き, 医療の質を落 とすようでは本末転倒である。

\section{$\mathrm{V} \quad$ 手術・麻酔部門の診療報酬請求 ${ }^{3)}$}

手術・麻酔関連の診療報酬請求項目には，管理料 として「手術前(後)医学管理料」「麻酔管理料」が あるが，前者は DPC制度にて包括され，後者の請 求には麻酔科医として常勤の標榜医が必要となる。 手術料としては，「診療点数早見表」等に記載があ

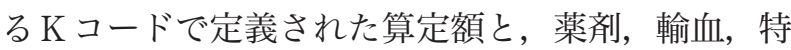
定保健医療材料などの点数を合わせたものが請求さ

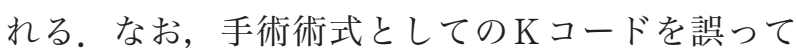
選択すると，DPC包括区分においても，時として 思わ損益を被ることがある(当院でも 1 症例当た り 100〜 300 万円の過少請求事例を数例経験してい る).

麻酔料に関しては, 硬膜外麻酔か全身麻酔かの違 い,ならびに手術時間延長に伴う加算等だけでなく, 時間外の手術開始や術中の体位，特殊手術(腹腔鏡 や人工心肺使用など）による加算等にも細かい注意 を払うべきである。

なお，一般には，手術・麻酔部門の診療報酬請求 は出来高算定であり, 長時間の麻酔・手術や大量の 薬剤使用は，そのまま収益増につながると考えられ る。しかし, 稚拙な手術等による麻酔・手術時間の 


\section{(1) 収益増}

\section{(収益) - (費用) $=$ 利益}

[a] 出来高算定部分の増収

手術件数の増加, 指導料·管理料等の増加

[b] 包括算定部分の増収

DPCコ一ディングの適正化 (アップコーディングではない)

[c] その他

機能係数の向上 ( 7 対 1 , 地域医療支援病院入院診療加算ほか)

新機能係数獲得 (様式1データの正確性, 効率性·複雑性ほか)

(2) 費用減 $=$ 包括算定部分の削減

ジェネリック薬の採用，医療材料の変更

高額検查の外来実施

DPC適応パスの採用?

图4 DPC 制度下で利益を上げるには？

延長は，本来不要な輸血の実施や術後合併症の発生 につながり，患者だけでなく病院経営面でも不利益 となることが危惧される。したがって，DPC制度 下で手術部門に最も期待することは，手術総件数を 増やすことであり, 麻酔科医・外科系医師・看護職 員等の確保，ならびに手術室を効率よく回転させる ためのマネジメントに尽きると考える。

\section{VI 院内のDPC 監査システムの重要性 ${ }^{1)}$}

DPC 対象病院では，適切な診断群分類を選択す ることが病院収益に直接影響するので，先述したよ うに出来高算定が主となる手術・麻酔部門において も，手術術式(Kコード等)の選択等に最善の注意を 払うべきである。また, 病院全体の取り組みとして, 診療報酬請求書(レセプト)を提出する前に，出来高 請求項目 (手術 - 麻酔, 術中使用薬剤 - 材料, 退院 時処方など)に対する病名確認だけでなく，診断群 分類が適切か否かの監査が重要と考える。特に，主 病名やKコードの選択を誤ると, 診断群分類の違 いで 1 日包括点数が異なるだけでなく, 時として包 括対象外の診断群分類となることもある。医師の多 くは，入院後早期に診断群分類を決定した後，診療 内容の変更時に診断群分類の見直しを怠りがちであ
る。したがって，医事課職員または DPC 請求担当 者によるスクリーニング的な監査は必須と考える. 当院では，医事課に診療情報管理士を参画させレセ プト提出前に診断群分類のチェックを行っている が，実際，DPCコーディングの適正化により 30〜 50 万点 /月の変更(増加) 効果がある。年間 4,000 6,000万円の増収が期待されるとすれば，優秀な人 材を医事課職員として配置することは病院経営面で も有用な対策と考える。

\section{Clinical Indicator の発信に向けて ${ }^{1), 5), 6)}$}

2007 年に聖路加国際病院から『Quality Indicator (「医療の質」を測る)』という本が出版された。日本 の医療界ではこれまで，自院の治療成績を積極的に 公開する姿勢に乏しく，一部の学会・研究会等で生 存率などが報告される程度であった。しかし，この 本に記載されている臨床指標には，平均在院日数や 病床稼働率といつた病院経営指標から，ガイドライ ン等で推奨されている薬剤の使用状況や適正検査の 実施率，そして 2 週間以内の退院サマリー完成率ま で，明らかに他施設とのベンチマークを意識した項 目が含まれている。これらの指標を継続的に把握し 公開するにあたっては，院内の病院情報システムへ 


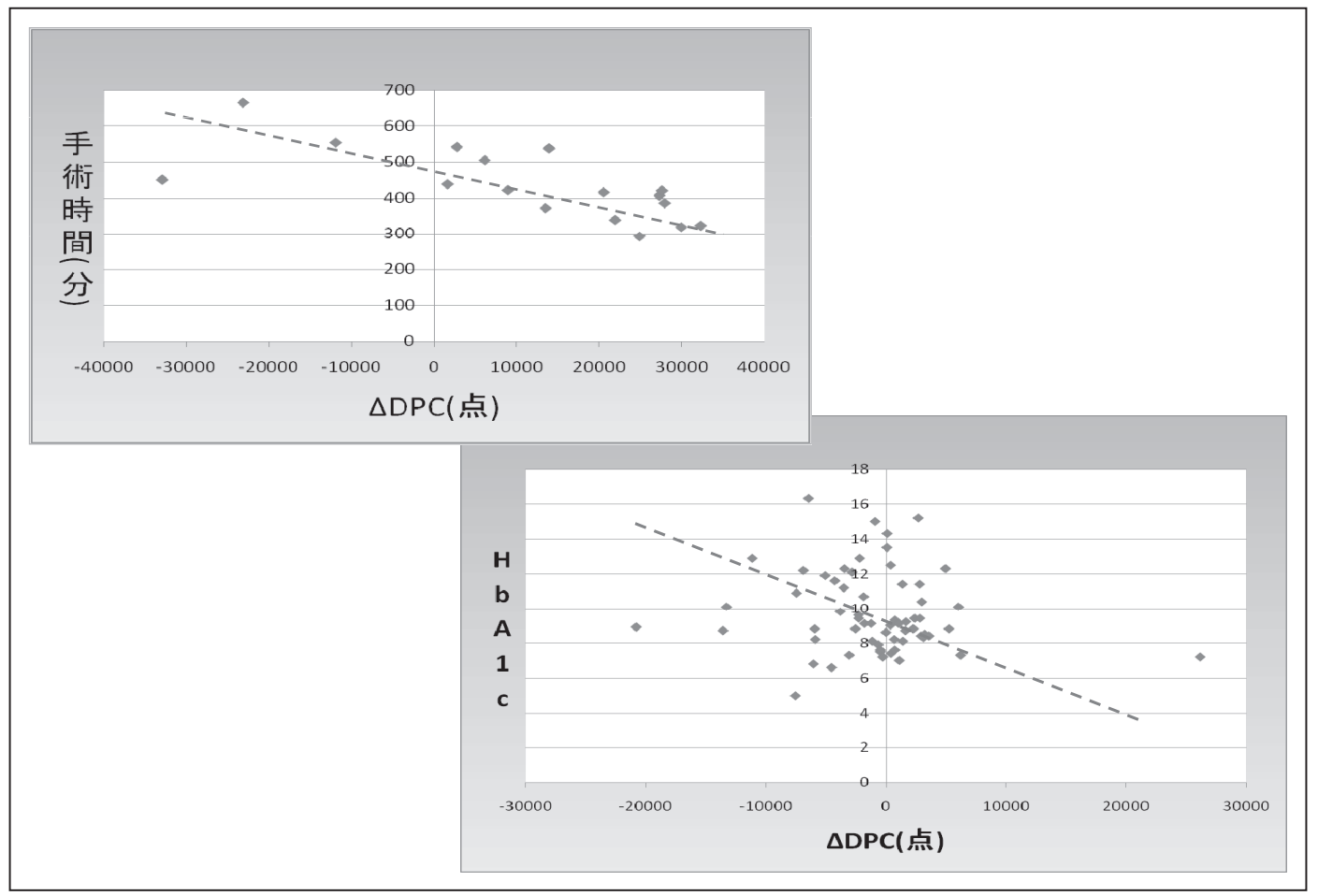

図 $5 \Delta D P C$ と手術時間・検査成績

の人的配置ならびに設備的な整備が必要と考える。 言い換えると，この種のデータや指標が容易に作成 できる院内環境がそこにあるということである。ま た, 院内で作成された臨床指標等を出版したり, ホ ームページで公開するということは，他人(他施設) からの評価を受ける準備，あるいは自信があること も意味している。

$\mathrm{DPC}$ 関連病院では，厚労省宛てに「様式 $1 」 と い$ う診療情報や「E，Fファイル」という出来高レセ プト情報等を, 統一形式でデータ提出することが義 務づけられている。実際，上記デー夕の提出期限を 守り，なおかつその精度が高くなければ，DPC対 象病院から追い出されることもありうるということ である。すなわち，DPC関連病院であるならば， 一定の臨床指標等を作成・検討するうえでの院内環 境は整えられているはずである。しかし，現実的に は，厚労省による DPCデー夕分析(評価)の現場へ のフィードバックがそしいこともあって，個々の
DPC関連病院が民間企業等との契約のもと, DPC 分析を依頼することで満足している状況が見受けら れる。

様式1やE，Fファイルは所詮加工されたデー夕 であり, 多くの貴重な診療情報(生デー夕) は院内の 病院情報システム内に眠っている。それらの診療情 報を自前で有効活用できない病院が多いことは残念 だが，DPC対象病院に限らず，今後の急性期病院 においては，院内の情報システムを有効活用してい く作業が重要と考える。

一方，現在の DPC 制度で提出が義務づけられて いるデータには検査成績などが含まれておらず，例 えば，聖路加国際病院の『Quality Indicator』で取 り上げられた「 $\mathrm{HbAlc} の$ 最終值が $6.5 \%, 7.0 \%$, 9.0\%未満の比率」に関していえば，多くの病院が手 作業による検討とならざるを得ないのが現実であろ う。当院は，いまだオーダリングシステム (NEC 社 製 PC-ORDERING/AD) の環境下ではあるが，厚生 
労働省電子的診療情報交換推進事業(Standardized Structured Medical Information Exchange : SSMIX) に先行する形で静岡県版電子カルテプロジェ クトを立ち上げた。その結果，同システムと各症例 の診断群分類をリンクさせることで，図5に示すよ うな $\triangle \mathrm{DPC}$ と手術時間・検査成績といった分析も 可能となる。すなわち，現状では厚労省に提出され ない診療情報の中に，医療の質の評価につながるデ ータが数多く存在することを再認識すべきである.

\section{まとめ}

DPC 制度下の診療報酬請求において，手術・麻 酔関連の項目は出来高算定であることから，同部門 の職員は本システムへの認識がそしくなりがちであ る。しかし，病院全体の経営戦略を考えるうえで, 手術・麻酔部門として手術件数を増やすことは当然 として，DPCコーディングの適正化を図るため手 術術式( $\mathrm{K}$ コード) 等の選択にも注意を払うことが重 要となる.
また，DPC対象病院は目先の利益のみにとらわ れず，院内情報システムの整備に投資することで， 潜在的データの利用も含め，臨床指標等を積極的に 公開していく姿勢が望まれる。

\section{参考文献}

1）小林利彦，堀宏治：DPC の来し方行く先一透明性と説 明責任への歩み一。医療夕イムス社, 東京, 2009

2）松田晋哉：臨床医のための DPC入門 (第 2 版)。じほう, 東京, 2009

3）医学通信社編集部編：DPC 点数早見表 診断群分類樹 形図と包括点数. 対象疾患一覧. 医学通信社, 東京, 2008

4) 平成 20 年度 DPC 対象病院の進渉状況等について (http://www-bm.mhlw.go.jp/shingi/2008/05/dl/s05093g.pdf)

5）福井次矢監修：Quality Indicator「医療の質」を測る一 聖路加国際病院の先端的試み一Vol.2. インターメデイ 力, 東京, 2008

6）医療マネジメント学会編：臨床指標の実際一医療の質 をはかるために一。じほう, 東京, 2005 


\title{
Usefulness and Limits of DPC Analysis When Considering Hospital Management Strategy
}

\author{
Toshihiko KOBAYASHI \\ Hamamatsu University School of Medicine, Affiliated Hospital
}

When establishing a management strategy for an acute hospital, knowledge of Diagnosis Procedure Combination(DPC) is indispensible. This also applies to the surgical as well as anesthesia personnel. In order to increase profit within a DPC system, the use of generic medicine, switching over to outpatient imaging scans, etc., have been highlighted, but an increase in revenue is anticipated through the appropriate coding, which can be also considered as the basis of the DPC system.

However, the benefits gained by a DPC targeted hospital switching over from a performance system should be invested in the maintenance of the hospital information system within the hospital, and an attitude of active public openness regarding clinical indicators is desired. In particular, continuing to acknowledge not only the DPC data presented currently to the Ministry of Health, Labour, and Welfare, but also the valuable raw data within the hospital, and consideration of the effective utilization of such data, is expected.

Key Words : DPC, Diagnosis Procedure Combination, Hospital management, Clinical indicator, Clinical coding

The Journal of Japan Society for Clinical Anesthesia Vol.31 No.1, 2011 